\title{
Conceptions of Philosophy
}

Royal Institute of Philosophy Supplement: 65

Edited by Anthony O’Hear 


\section{Royal Institute of Philosophy Supplements}

The Royal Institute of Philosophy Supplements are published twice a year. Institutional subscribers to the journal Philosophy receive the supplements as part of their subscription. The following supplements are available to purchase as books.

\begin{tabular}{|c|c|c|}
\hline Volume 37 & 1994 & $\begin{array}{l}\text { Philosophy, Psychology and } \\
\text { Psychiatry }\end{array}$ \\
\hline 38 & 1995 & Philosophy and Technology \\
\hline 39 & 1995 & $\begin{array}{l}\text { Karl Popper: Philosophy and } \\
\text { Problems }\end{array}$ \\
\hline 40 & 1996 & Philosophy and Pluralism \\
\hline 41 & 1996 & Verstehen and Human Understanding \\
\hline 42 & 1997 & Thought and Language \\
\hline 43 & 1998 & $\begin{array}{l}\text { Current Issues in Philosophy } \\
\text { of Mind }\end{array}$ \\
\hline 44 & 1999 & German Philosophy since Kant \\
\hline 45 & 1999 & Philosophy and Public Affairs \\
\hline 46 & 2000 & Logic, Cause \& Action \\
\hline 47 & 2000 & $\begin{array}{l}\text { Philosophy, the Good, the True } \\
\text { and the Beautiful }\end{array}$ \\
\hline 48 & 2001 & Philosophy at the New Millennium \\
\hline 49 & 2001 & Naturalism, Evolution and Mind \\
\hline 50 & 2002 & Time, Reality \& Experience \\
\hline 51 & 2002 & Logic, Thought and Language \\
\hline 52 & 2003 & Philosophy and the Emotions \\
\hline 53 & 2003 & Minds and Persons \\
\hline 54 & 2004 & Modern Moral Philosophy \\
\hline 55 & 2004 & Agency and Action \\
\hline 56 & 2005 & Philosophy, Biology and Life \\
\hline 57 & 2005 & The Philosophy of Need \\
\hline 58 & 2006 & Political Philosophy \\
\hline 59 & 2006 & Preferences and Well-Being \\
\hline 60 & 2007 & Narrative and Understanding Persons \\
\hline 61 & 2007 & Philosophy of Science \\
\hline 62 & 2008 & $\begin{array}{l}\text { Being: Developments in } \\
\text { Contemporary Metaphysics }\end{array}$ \\
\hline 63 & 2008 & $\begin{array}{l}\text { Kant and Philosophy } \\
\text { of Science Today }\end{array}$ \\
\hline 64 & 2009 & Epistemology \\
\hline
\end{tabular}

(ISBN 0521469023)

(ISBN 0521558166)

(ISBN 0521558158)

(ISBN 0521567505)

(ISBN 0521587425)

(ISBN 0521587417)

(ISBN 0521639271)

(ISBN 0521667828)

(ISBN 0521667844)

(ISBN 0521785103)

(ISBN 0521785111)

(ISBN 0521005086)

(ISBN 0521003733)

(ISBN 0521529670)

(ISBN 0521529662)

(ISBN 0521537347)

(ISBN 0521537339)

(ISBN 0521603269)

(ISBN 0521603560)

(ISBN 0521678455)

(ISBN 0521678447)

(ISBN 0521695597)

(ISBN 0521695589)

(ISBN 9780521714099)

(ISBN 9780521718967)

(ISBN 9780521735445)

(ISBN 9780521748513)

(ISBN 9780521138581)

From Volume 13 onwards the Series is published by Cambridge University Press and some earlier titles are also available.

This journal issue has been printed on FSC-certified paper and cover board. FSC is an independent, non-governmental, not-for-profit organization established to promote the responsible management of the world's forests. Please see www.fsc.org for information. 


\section{Conceptions of Philosophy}

ROYAL INSTITUTE OF PHILOSOPHY SUPPLEMENT: 65

EDITED BY

Anthony O’Hear

\section{CAMBRIDGE UNIVERSITY PRESS}


PUBLISHED BY THE PRESS SYNDICATE OF THE UNIVERSITY OF CAMBRIDGE

The Pitt Building, Trumpington Street, Cambridge, CB2 1RP, United Kingdom

CAMBRIDGE UNIVERSITY PRESS

The Edinburgh Building, Cambridge CB2 8RU, United Kingdom

32 Avenue of the Americas, New York, NY 10013-2473, USA

477 Williamstown Road, Port Melbourne, VIC 3207, Australia Ruiz de Alarcón 13, 28014 Madrid, Spain

Dock House, The Waterfront, Cape Town 8001, South Africa

(C) The Royal Institute of Philosophy and the contributors 2009

Printed in the United Kingdom at the University Press, Cambridge Typeset by Techset Composition Ltd, Salisbury, UK

A catalogue record for this book is available from the British Library

ISBN 9780521138574

ISSN 1358-2461 


\section{Contents}

Preface $\quad$ V

List of Contributors vii

Visions of Philosophy 1

DAVID E. COOPER

Listening to Clifford's Ghost 15

PETER VAN INWAGEN

Metaphysical (Im)mortality and Philosophical Transcendence 37 JOHN HALDANE

My Conception of Philosophy $\quad 57$ BRYAN MAGEE

$\begin{array}{ll}\text { Modern Philosophy } & 71\end{array}$ JONATHAN HARRISON

Philosophical Amnesia $\quad 93$ NICHOLAS CAPALDI

Philosophy: A Contribution, not to Human Knowledge, but to Human Understanding

P. M. S. HACKER

Can Philosophy be a Rigorous Science? HERMAN PHILIPSE

The Doctor of Philosophy Will See You Now CHRISTOPHER COOPE

Plotinus: Charms and Countercharms STEPHEN R. L. CLARK

What is Humane Philosophy and Why is it At Risk? JOHN COTTINGHAM

Why is There Something Called Philosophy Rather than Nothing? 257 STEPHEN MULHALL

Philosophy and the Sciences After Kant 275 MICHELA MASSIMI

The Inward Turn CHARLES TRAVIS

Philosophy - Wisdom or Technique?

ANTHONY O'HEAR 


\section{List of Contributors}

David Cooper, University of Durham

Peter van Inwagen, University of Notre Dame

John Haldane, University of St. Andrews

Bryan Magee, Keble College, Oxford

Jonathan Harrison, Universities of Nottingham and Cambridge

Nicholas Capaldi, Loyola University

P.M.S. Hacker, St. John's College, Oxford

Herman Philipse, University of Utrecht

Christopher Coope, University of Leeds

Stephen Clark, University of Liverpool

John Cottingham, University of Reading

Stephen Mulhall, New College, Oxford

Michela Massimi, University College London

Charles Travis, King's College London

Anthony O’Hear, University of Buckingham 